\title{
A Rare Case of Hemoglobin E/Beta-Thalassemia and Systemic Lupus Erythematosus
}

\author{
Ibrahim Khamees ${ }^{1}$, Ibrahim Mohammad Obeidat ${ }^{1}$, Waail Rozi ${ }^{1}$, Mohamed A. Yassin ${ }^{2}$ \\ 1. Internal Medicine, Hamad Medical Corporation, Doha, QAT 2. Hematology and Oncology, Hamad General Hospital, \\ Doha, QAT
}

Corresponding author: Ibrahim Khamees, ibrahim_khamees@hotmail.com

\begin{abstract}
Systemic lupus erythematosus (SLE) is a systemic autoimmune disease, with multisystemic involvement. Hemoglobin $\mathrm{E} /$ beta-thalassemia ( $\mathrm{HbE} /$ beta-thalassemia) is the genotype responsible for approximately onehalf of all severe beta-thalassemia worldwide. When beta-thalassemia and SLE coexist, SLE seems to have a more severe course. Here we report a 32-year-old female who presented with dizziness and fatigue was found to have severe hemolytic anemia with thrombocytopenia. Upon further evaluation, she was diagnosed with $\mathrm{HbE}$ /beta-thalassemia and SLE, which is a very rare association. In SLE patients, anemia usually results from the disease itself, but it is important to think of other coexisting conditions like thalassemia.
\end{abstract}

Categories: Internal Medicine, Rheumatology, Hematology

Keywords: hemoglobin e/beta-thalassemia, systemic lupus erythematosus, hemolytic anemia

\section{Introduction}

Systemic lupus erythematosus (SLE) is a multisystem chronic inflammatory disease of autoimmune etiology, with the hematologic system being affected in most cases. SLE can cause anemia in multiple ways, one of them is hemolytic anemia. It can also cause thrombocytopenia especially if associated with antiphospholipid antibody syndrome involving autoantibodies against platelets, glycoprotein IIb/IIIa or thrombopoietin receptor [1]. With that being mentioned, some patients with SLE can have another condition that can cause anemia as well. It was found that the prevalence of beta-thalassemia in patients with SLE is lower than that in general population, but if coexistence happens, SLE seems to have a more severe course [2].

Received 08/07/2020

Review began 08/17/2020

Review ended 09/02/2020

Published 09/09/2020

(๑) Copyright 2020

Khamees et al. This is an open access article distributed under the terms of the Creative Commons Attribution License CC-BY 4.0., which permits unrestricted use, distribution, and reproduction in any medium, provided the original author and source are credited.
Hemoglobinopathies are considered the commonest recessive monogenic disorders in the world, and they constitute a major burden on the financial and health care systems globally. Beta-thalassemia presents with either decreased $(\beta+)$ or absence $(\beta$ o) of the beta-globin chains in the HbA protein, which leads to buildup of extra unbound alpha-globin chains in the erythroid precursors in the bone marrow and in the red blood cells (RBCs), resulting in ineffective erythropoiesis and hemolysis. Around $1.5 \%$ of the world population are heterozygotes (carriers) of the beta-thalassemias; there is a high incidence in the Middle East, the Indian subcontinent, Southeast Asia, and Melanesia to the Pacific Islands [3].

Chronic blood transfusion (CBT) is essential in the management of individuals with beta-thalassemia major. However, it has major complications including iron overload that necessitates regular monitoring and treatment by long-term iron chelation therapy to protect the patients from endocrinopathies and cardiomyopathies, which can be fatal [4-7]. Skeletal changes may result from the expansion of the bone marrow, and development of masses from extramedullary hematopoiesis. In spite of that, CBT causes iron overload that requires monitoring and management through long-term iron chelation therapy [8].

\section{Case Presentation}

A 32-year-old female patient presented with a history of dizziness and fatigue increasing in the last few weeks. She came to the country around seven months back and mentioned having multiple blood transfusions in her home country for anemia. On examination, the patient had severe pallor, jaundice and hepatosplenomegaly.

Initial laboratory investigations are given in Table 1 


\section{Cureus}

\begin{tabular}{|c|c|c|}
\hline Investigation & Result & Normal range \\
\hline White blood cell count & $4.5 \times 10^{3} / \mu \mathrm{L}$ & $4-10 \times 10^{3} / \mu \mathrm{L}$ \\
\hline Red blood cell count & $1.7 \times 10^{6} / \mu \mathrm{L}$ & $3.8-4.8 \times 10^{6} / \mu \mathrm{L}$ \\
\hline Hemoglobin & $3.1 \mathrm{gm} / \mathrm{dL}$ & $12-15 \mathrm{gm} / \mathrm{dL}$ \\
\hline Hematocrit & $11.4 \%$ & $36 \%-46 \%$ \\
\hline Mean corpuscular volume & $65.9 \mathrm{fL}$ & 83-101 fL \\
\hline Platelet count & $72 \times 10^{3} / \mu \mathrm{L}$ & $50-400 \times 10^{3} / \mu \mathrm{L}$ \\
\hline Reticulocyte \% & $4.2 \%$ & $0.5 \%-2.5 \%$ \\
\hline Reticulocyte index & $0.46 \%$ & $>2.5 \%$ \\
\hline Lactate dehydrogenase & $933 \mathrm{U} / \mathrm{L}$ & 135-214 U/L \\
\hline Haptoglobin & $>10 \mathrm{mg} / \mathrm{dL}$ & $30-200$ mg/dL \\
\hline Total bilirubin & $57 \mu \mathrm{mol} / \mathrm{L}$ & $0-21 \mu \mathrm{mol} / \mathrm{L}$ \\
\hline Direct bilirubin & $12 \mu \mathrm{mol} / \mathrm{L}$ & $0-5 \mu \mathrm{mol} / \mathrm{L}$ \\
\hline Ferritin & $2,519 \mu \mathrm{g} / \mathrm{L}$ & $12-160 \mu \mathrm{g} / \mathrm{L}$ \\
\hline Iron & $43 \mu \mathrm{mol} / \mathrm{L}$ & $6-35 \mu \mathrm{mol} / \mathrm{L}$ \\
\hline Fe saturation & $90 \%$ & $15 \%-45 \%$ \\
\hline Direct antiglobulin test & +2 for immunoglobulin G & \\
\hline Elution test & Negative & \\
\hline
\end{tabular}

\section{TABLE 1: Initial laboratory investigations}

Peripheral smear (Figure 1) showed moderate hypochromic microcytic anemia with scattered polychromatic cells, many nucleated RBCs and significant anisopoikilocytosis, including many scattered tear drops, ovalocytes, schistocytes, irregularly contracted cells and some microspherocytes.

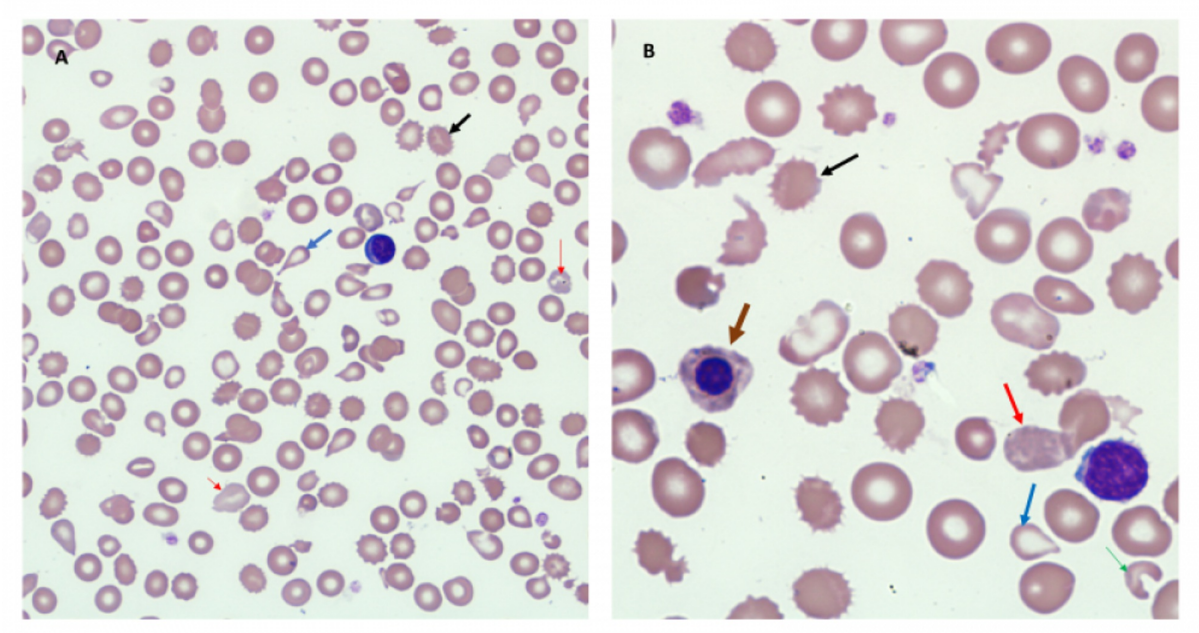

\section{FIGURE 1: Peripheral blood smear}

Image $A$ is low power view. Image B is high power view. Both images show hypochromic microcytic anemia with scattered polychromatic cells (red arrow), Nucleated red blood cells (brown arrow) and significant anisopoikilocytosis including many scattered tear drops (blue arrow), ovalocytes, schistocytes (green arrow), burr cells (black arrow) and some microspherocytes. 
Kidney function, international normalized ratio and fibrinogen were all normal. Ultrasound of the abdomen was done, which was positive for hepatosplenomegaly. The patient was resuscitated with packed RBC transfusion and admitted. With the history of multiple blood transfusions in the past, the iron overload (probably due to multiple blood transfusions) and the low mean corpuscular volume (MCV), hemoglobin electrophoresis was sent and it showed the findings in Table 2, based on that the patient was diagnosed with $\mathrm{HbE} /$ beta-thalassemia.

\begin{tabular}{|l|l|}
\hline Hemoglobin type & Percentage \\
\hline $\mathrm{Hb} \mathrm{A}$ & 00 \\
$\mathrm{Hb} \mathrm{A2}$ & 2.0 \\
$\mathrm{Hb} \mathrm{F}$ & 25 \\
$\mathrm{Hb} \mathrm{S}$ & 00 \\
$\mathrm{Hb} \mathrm{E}$ & 73 \\
\hline
\end{tabular}

TABLE 2: Hemoglobin electrophoresis

Autoimmune workup revealed positive antinuclear antibody (ANA), anti-double-stranded DNA (anti-dsDNA) and low complement protein 3 (C3), so the patient was diagnosed with SLE and started on hydroxychloroquine. The patient was hospitalized for five days, during which Hb picked up to $9.9 \mathrm{gm} / \mathrm{dL}$ and platelets count decreased to $38 \times 10^{3} / \mu \mathrm{L}$, and was discharged with a plan to follow complete blood cell (CBC) in the clinic after two weeks. However, upon repeating CBC after two weeks, the patient had anemia with $\mathrm{Hb}$ of $6.9 \mathrm{mg} / \mathrm{dL}$, white blood cell (WBC) of $3.7 \times 10^{3} / \mu \mathrm{L}$, absolute neutrophilic count of $2.2 \times 10^{3} / \mu \mathrm{L}$ and platelet count of $12 \times 10^{3} / \mu \mathrm{L}$, so she was admitted again. She complained of easy fatigability and exertional shortness of breath, but no apparent bleeding from any site. On examination, she had pallor, hepatosplenomegaly but no skin rash.

Her lab investigations that time also revealed hemolytic anemia with low reticulocyte index 0.55 and severe thrombocytopenia $12 \times 10^{3} / \mu \mathrm{L}$, increased (anti-ds-DNA) titer, low C3 and normal kidney function test. She was managed as a case of SLE flare causing thrombocytopenia and anemia complicated by thalassemia, for which she was started on oral prednisolone $1 \mathrm{mg} / \mathrm{kg}$ which was changed to intravenous methylprednisolone $10 \mathrm{mg} / \mathrm{kg}$, along with platelets, fresh-frozen plasma and packed RBC transfusions. She was also started on deferasirox (Jadenu) $720 \mathrm{mg}$ daily due to iron overload. In the next few days, the platelet count improved to $47 \times 10^{3} / \mu \mathrm{L}$ and her $\mathrm{Hb}$ stabilized around $9 \mathrm{mg} / \mathrm{dL}$, so she was discharged on oral prednisolone with a followup after one week to follow CBC. In the follow-up, her platelet count was $119 \times 10^{3} / \mu \mathrm{L}$ and her Hb was 9.3 $\mathrm{mg} / \mathrm{dL}$, so prednisolone was tapered with close follow-up in rheumatology and hematology clinics.

\section{Discussion}

We described a patient who has $\mathrm{HbE}$ /beta-thalassemia double heterozygosity, admitted with severe anemia and thrombocytopenia, found to have SLE. The association between beta-thalassemia in general and SLE is rare, and it is rarer in $\mathrm{HbE}$ /beta-thalassemia based on the reported case all over the world. However, near the beta-globin locus at $11 \mathrm{p} 15.5$, there are specific immunity genes, which match with the autoimmunity susceptibility [9].

Hematologic abnormalities are common in SLE, and all three blood cell lines can be affected. Anemia of chronic disease is the most common type of anemia in SLE patients, autoimmune hemolytic anemia is relatively rare and severe thrombocytopenia is rare as well [10].

In general, $\mathrm{HbE}$ /beta-thalassemia is a thalassemia syndrome of intermediate severity with a diverse clinical spectrum. Compared to a normal individual, $\mathrm{HbA}$ is replaced by $\mathrm{HbE}$ and $\mathrm{HbF}$ in patients with $\mathrm{HbE} /$ betathalassemia. $\mathrm{HbE}$ constitutes between $30 \%$ and $70 \%$ of the hemoglobin with the rest $\mathrm{HbF}$. In some cases of $\mathrm{HbE}$ thalassemia as $\mathrm{HbE}$ beta+ thalassemia, different mutations lead to variable amounts of $\mathrm{HbA}$, which causes variable levels of disease severity [11].

In one study that included 177 patients with SLE, there were 17 patients with beta-thalassemia. This study concluded that the prevalence of beta-thalassemia in patients with SLE seems to be lower than that in the general population. However, when the two conditions coexist, SLE seems to have a more severe course. The incidence of complications was more severe in SLE with beta-thalassemia. However, the reason behind that was not clear. It could be related to low complement 3 and complement 4 , and/or due to presence of anti- 
SSA autoantibodies (anti-Sjögren's syndrome-related antigen A autoantibodies, also called anti-Ro antibodies). Also, higher occurrence of atherosclerotic events and loss of the ability to bind immune complexes have been described in beta-thalassemia which could be related to a more severe disease [2].

In one literature review, the authors highlighted the diagnostic difficulty of SLE in patients with other type of hemolytic anemia which is sickle cell disease (SCD). They attributed that to the similar manifestations of both diseases, including anemia and skeletal pain. They concluded that certain features might alert the physicians to the possibility of both diseases coexistence like joint pain resistant to usual analgesic measures, presence of proteinuria or presence of leukopenia and thrombocytopenia in SCD patients [12].

Many cases reported association of beta-thalassemia trait and SLE, but upon reviewing the literature we found only one case about $\mathrm{HbE}$ /beta-thalassemia and SLE disease [13]. In our case, we faced more severe presentation in the hematological system. Meanwhile for the patient who was diagnosed previously with thalassemia and developed worsening in her hematological cell lines, it is worthy to investigate for possible other coexisting causes. Peripheral smear finding and autoimmune antibody can give us clue about the underlying cause and the need for further testing.

\section{Conclusions}

The association between beta-thalassemia in general and SLE is rare, and it is rarer in HbE/beta-thalassemia and SLE based on the reported case all over the world. More severe symptoms can present in concomitant disease. This warrants early suspicion and diagnosis of other diseases that might worsen the primary disease.

\section{Additional Information \\ Disclosures}

Human subjects: All authors have confirmed that this study did not involve human participants or tissue. Conflicts of interest: In compliance with the ICMJE uniform disclosure form, all authors declare the following: Payment/services info: All authors have declared that no financial support was received from any organization for the submitted work. Financial relationships: All authors have declared that they have no financial relationships at present or within the previous three years with any organizations that might have an interest in the submitted work. Other relationships: All authors have declared that there are no other relationships or activities that could appear to have influenced the submitted work.

\section{References}

1. Justiz Vaillant AA, Goyal A, Bansal P, Varacallo M: Systemic Lupus Erythematosus (SLE). StatPearls Publishing, Treasure Island, FL; 2020.

2. Castellino G, Govoni M, Padovan M, Rizzo N, Trotta F: Beta thalassaemic trait and systemic lupus erythematosus. Ann Rheum Dis. 2005, 64:653-654. 10.1136/ard.2004.023689

3. De Sanctis V, Kattamis C, Canatan D, et al.: $\beta$-thalassemia distribution in the old world: an ancient disease seen from a historical standpoint. Mediterr J Hematol Infect Dis. 2017, 9:e2017018.

4. Kanbour I, Chandra P, Soliman A, et al.: Severe liver iron concentrations (LIC) in 24 patients with $\beta$ thalassemia major: correlations with serum ferritin, liver enzymes and endocrine complications. Mediterr J Hematol Infect Dis. 2018, 10:e2018062. 10.4084/MJHID.2018.062

5. Soliman AT, Yasin M, El-Awwa A, De Sanctis V: Detection of glycemic abnormalities in adolescents with beta thalassemia using continuous glucose monitoring and oral glucose tolerance in adolescents and young adults with $\beta$-thalassemia major: pilot study. Indian J Endocrinol Metab. 2013, 17:490-495. 10.4103/22308210.111647

6. De Sanctis V, Elsedfy H, Soliman AT, et al.: Acquired hypogonadotropic hypogonadism (AHH) in thalassaemia major patients: an underdiagnosed condition?. Mediterr J Hematol Infect Dis. 2016, 8:e2016001. 10.4084/MJHID.2016.001

7. Soliman A, Yassin M, Al Yafei F, Al-Naimi L, Almarri N, Sabt A, De Sanctis V: Longitudinal study on liver functions in patients with thalassemia major before and after deferasirox (DFX) therapy. Mediterr J Hematol Infect Dis. 2014, 6:e2014025. 10.4084/MJHID.2014.025

8. Yassin MA, Soliman AT, De Sanctis V, Abdelrahman MO, Bedair EM, AbdelGawad M: Effects of the antireceptor activator of nuclear factor kappa B ligand denusomab on beta thalassemia major-induced osteoporosis. Indian J Endocrinol Metab. 2014, 18:546-551. 10.4103/2230-8210.137516

9. Altinoz MA, Gedikoglu G, Deniz G: $\beta$-Thalassaemia trait association with autoimmune diseases: $\beta$-globin locus proximity to the immunity genes or role of haemorphins?. Immunopharmacol Immunotoxicol. 2012, 34:181-190. 10.3109/08923973.2011.599391

10. Newman K, Owlia MB, El-Hemaidi I, Akhtari M: Management of immune cytopenias in patients with systemic lupus erythematosus: old and new. Autoimmun Rev. 2013, 12:784-791. 10.1016/i.autrev.2013.02.001

11. Fucharoen S, Weatherall DJ: The hemoglobin E thalassemias. Cold Spring Harb Perspect Med. 2012, 2:a011734. 10.1101/cshperspect.a011734

12. Kaloterakis A, Filiotou A, Haziyannis S, Vaiopoulos G, Lutradi-Anagnostou A: Sickle cell/ß0-thalassemia and systemic lupus erythematosus. Lupus. 1999, 8:778-779. 10.1191/096120399678840972

13. Paul R, Seal K, Das S, Chakravarti HN, Bhattacharya R: E beta thalassemia complicated by steroid responsive auto immune hemolytic a nemia due to systemic lupus erythematosus. Int Res J Pharm. 2013, 4:241-242. 


\section{Cureus}

$10.7897 / 2230-8407.04450$ 